\title{
The unlikely advocates of media literacy education: Jean-Jacques Rousseau and John Stuart Mill
}

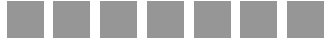 \\ Anamaria Neag \\ hungarian aCAdemy of SCIENCES Centre for SOCIal SCIENCES, hungary \\ DOI: 10.19195/1899-5101.9.1(16).7
}

\begin{abstract}
Media literacy is defined as a set of competencies that helps people critically analyze, understand and create media messages. Teaching children to become media literate emerged as a new field of education in the second half of the 20th century. While the pioneering work of Dewey, Freinet, Gerbner, Hall and Whannel (as cited by Cappello et al., 2011) was influential in the development of media literacy, this article argues for the importance of positioning media literacy in a broader theoretical context. Therefore, the article presents an analysis of media literacy education by relying on two of the founders of modern social thought: Rousseau and Mill. The article demonstrates how Rousseau's treatise is as timely as ever when it comes to understanding the educational aims of media literacy. Similarly, Mill's approach helps us in understanding the importance of media literacy education not only in school curricula, but also in many other aspects of social life.
\end{abstract}

KEYWORDS: media literacy, media education, Jean-Jacques Rousseau, John Stuart Mill.

\section{INTRODUCTION}

There are numerous definitions of media literacy. Perhaps the most widely used is provided by the National Association for Media Literacy Education:

[...] media literacy is seen to consist of a series of communication competencies, including the ability to access, analyze, evaluate, and communicate information in a variety of forms, including print and non-print messages. Media literacy empowers people to be both critical thinkers and creative producers of an increasingly wide range of messages using image, language, and sound. (NAMLE, n.d.)

Media literacy has emerged as a new field of scientific inquiry at the crossroad of media studies and education. Because of its relative novelty, scholars are still debating how it should be named (media literacy versus digital literacy, versus media and information literacy and so on), how it should be defined, and which authors should be in the canons of the field. 
Similarly, it is not easy to pinpoint the theories that are to be considered the theoretical basis of media literacy. Cappello, Felini and Hobbs (2011) mention authors such as Dewey, Freinet, Laporta, Gerbner, Hall and Whannel, Eco, McLuhan, Horkheimer and Adorno, Althusser, Freire, Baacke, Porcher, or Postman (as cited by Cappello et al., 2011), whose work was significant in the development of media literacy. Cappello, Felini and Hobbs (2011) also remark that we can trace a multitude of theoretical roots and perspectives at the origins of media literacy: Marxian and neo-Marxian sociology of culture, activism in education, history of communication and culture, critical pedagogy, or educational theory. In addition to the above- mentioned scholars, Kellner and Share (2007) argue for a new type of media literacy - critical media literacy - that should draw "from the multidisciplinary field of cultural studies" (p. 11). Thus Kellner and Share (2007) also incorporate the work of the Frankfurt and Birmingham School in shaping the future of media literacy education.

From this short and condensed overview it becomes clear that media literacy as a field is still being debated and contested. In this present paper, my aim is to situate media literacy in a broader theoretical context and demonstrate that the aims of media literacy education can be analyzed by relying on two of the founders of modern social thought: Rousseau and Mill. The two philosophers are renowned for their radical theories of political education. Rousseau and Mill consider education a means to "achieve a transformation of attitudes to man and society" (Parry, 2001, p. 248). Media literacy educators ultimately have similar goals: to create "a just society through critical civic engagement" (Thevenin \& Mihailidis, 2012, p. 61).

I will thus explore media literacy at the crossroads of education and media. For investigating media literacy from this point of view I will start with Rousseau's Emile, published in 1762, in which a new, perhaps utopian, education method is sketched and demonstrate how Rousseau's treatise is as timely as ever when it comes to understanding the educational aims of media literacy.

The second author Mill will help us understand the overall role of education and he is the famous methodological individualist, Mill. His approach will shed a different light on this topic compared to the collectivist Rousseau, but it will advance the importance of this specific subject not only in school curricula, but also in many other aspects of social life.

\section{AIMS OF MEDIA LITERACY EDUCATION}

For setting the stage of this present quest, I will begin with an outline of the major aims of media literacy education, as defined by a number of relevant actors in the field. As I mentioned earlier - because of the relative novelty and dynamically changing nature of the field - there are still disputes about definitions, traditions and overall aims. In the Core Principles of Media: 
The purpose of media literacy education is to help individuals of all ages develop the habits of inquiry and skills of expression that they need to be critical thinkers, effective communicators and active citizens in today's world. (NAMLE, n.d.)

The European Commission (2015) defines media literacy as:

[...] the ability of people to access, understand, create and critically evaluate different types of media. [...] Media literacy is vital for economic growth and job creation. Digital technologies are a key driver of competitiveness and innovation in the media, information, and communication technology sectors.

Beyond these major actors, there are some differences among the definitions used by European Union countries as well. For instance in Hungary the National Core Curriculum (A Nemzeti..., 2012) defines the aim of media literacy education as a means through which children can become:

[...] competent participants of the global mediated public: to understand the language of new and old media. Media literacy education prepares [students] for the culture of participatory democracy and value-based everyday life that is being influenced by the media. It does so through developing a critical attitude and through its action-oriented attitude. (2012, p. 10644)

Although we can obviously spot some variations among these goals, there are some clear commonalities as well: critical usage and analysis of media messages, creating media content in a variety of forms, reflecting or making sense of media texts, but also an active participation in the mediated public. In the following section, I will analyze these aims in the light of Rousseau's Émile. Afterwards I will argue that the aims of media literacy education support the overall development of citizens. Mill's concept of utility will offer the theoretical framework in this argument.

\section{ÉMILE — A MEDIA LITERATE CHILD?}

Rousseau, a political and social thinker, became an influential education theorist by writing the book Émile, or On Education. Émile was and still is today, in some aspects, a work of educational reform. The book was considered quite provocative at that time, and one of the many criticisms it received was that this type of education is, in fact, impracticable.

One of the main themes of Rousseau is that people by nature are good, it is society that corrupts:

God makes all things good; man meddles with them and they become evil ... he will have nothing as nature made it, not even man himself, who must learn his paces like a saddle-horse, and be shaped to his master's taste like the trees in his garden. (Rousseau, 1993, p. 3)

This is the first point where we can connect media literacy education to Rousseau's argument. In many instances, one can read about the necessity of training 
students to become relevant actors in the economy, to get good jobs or to start one's own company. However, Rousseau in fact talks about education, not training, which is completely different. He highlights the importance of developing a child's own thinking:

[...] my Émile, who has been carefully guarded for eighteen years with the sole object of preserving a right judgment and a healthy heart. (1993, p. 244)

Thinking and judgment have been at the heart of media literacy education. For having a critical approach towards mass-media texts, the first and foremost principle of media literacy is exactly active inquiry. Or, as Rousseau puts it, Émile has to think for himself and thus be preserved from error and prejudice. This is the only way he will not be in danger of being corrupted by society. Thinking people would be called in media literacy terms "active audience": those who can judge media content and decide on their own - one of the major aims of media education.

Jimack observes that Rousseau is critical of the very foundations of educational practice. He proposes:

[...] a new way of looking at children and their education; the pedagogical doctrine of Émile is a structured whole, in which each age is important both in its own right - children are at last seen as children — and as a preparation for future development. (1993, p. xxxiii)

Today this seems commonsense. Yet for media literacy practitioners it is the basis of their pedagogy. If we examine media literacy curricula, we can find a wealth of teaching materials that support the argument of a child-centered education. These programs have specific curricula, programs and activities taking into consideration the age, the development, the previous knowledge, and most importantly, the societal conditions in which children are living in. For instance there are large differences in media literacy programs in the EU countries, where the focus is on online bullying, for instance, and Brazil, where the focus is more on equitable access to information (see for instance RobbGrieco, 2014).

Rousseau believes that good education means protecting the child from the corrupting influence of society. This is why he teaches Émile in the countryside, for instance. In this aspect media literacy seems to be in trouble, though. Initially the main aim of media literacy was to protect children from harmful media content, while today most scholars agree that children should not be kept away from the media, but taught to understand it critically. So would Rousseau despise media usage? It is a difficult question, since he considers books and reading "the curse of childhood" (1993, p. 85), except one - Robinson Crusoe. In the meantime, Rousseau places much emphasis on the development of senses for the whole of education. He says:

His sense experiences are the raw material of thought; they should, therefore, be presented to him in fitting order. (1993, p. 31) 
Rousseau obviously thought about having the child outdoors, running about in the meadow, and so on. However, in today's world, media are so pervasive, built into our everyday lives, that it is quite difficult to ignore it. While this might seem a provocative, I would argue that today children's ability to use touch screen tablets, phones and so on is also part of children's development of senses. Moreover, Rousseau says:

Give your child no verbal lessons; he should be taught by experience alone. (1993, p. 58)

Rushkoff (1996), for instance, asserts that today's young generations growing up in Western societies, experience the world mostly not through physical boundaries, but through screens. Rousseau values learning through experience, and similarly media literacy experts recognize and advocate for the importance of media experiences. While, of course, one could argue that media cannot be compared to natural experiences, I would highlight once again that in today's world it is getting ever more difficult to separate our offline and virtual culture.

Going further Rousseau believes that;

[...] the child must learn only what he wants to learn; his curiosity for the subject must be aroused and he must always be able to see its utility for him. (1993, p. 83)

This is a provocative idea even now: can we or should we let a child decide on what he wants to learn? Rousseau believes that conventional education is wrong because pupils have to study speculative disciplines that cannot provide practical knowledge (Cranston, 1991). As presented previously, media literacy is rarely institutionalized and in many countries it is an elective class or an after-school activity. Therefore, it is still somewhat free of institutional constraints in its practice. Many of the curricula made for this subject highlights the utilitarian aspect Rousseau is talking about. For instance Scheibe and Rogow (2008) advise teachers to be flexible in assignments, stimulate interest in a new topic or facilitate use of a range of media formats to express students' opinions and illustrate their understanding of the world. Similarly Hobbs says that there are a multitude of reasons why educators introduce media literacy as part of the curriculum: from seeing it as a tool to make contemporary education relevant for students (by building links between the classroom and everyday culture) to seeing media literacy as

[...] a way to give children the opportunity to tell their own stories and better understand the power of those who shape the stories of our culture and our times. (Hobbs, 1996, p. 104)

There are two more aspects that connect media literacy education to Rousseau: one is the importance of manual trade and the other is the development of the aesthetic faculties in adolescence.

Rousseau sees as an important part of education the learning of manual trade, which is carpentry in the case of Émile. He sees this as a fulfillment of a civic re- 
sponsibility and securing Émile's future and his independence. However, what is the connection between media literacy and manual trade? The question is indeed appropriate. I would argue that one of the aims of media education is exactly the creation of media products. The question of production is actually very important since media literacy is not only about analyzing and evaluating media, but also about creating media in a variety of forms, to express opinions and feelings through writing, speaking, filming, etc. While this is not exactly carpentry, we can draw a parallel with today's high-tech world. I would suggest that this idea is not very different to Rousseau's, and even more since media production today might be regarded as a form of youth empowerment, but also a civic exercise (Fishekeller, 2011). Furthermore, media literacy and digital skills are essential prerequisites for securing one's future and independence.

Finally, in Book IV Rousseau talks about finishing Émile's education:

We made him a worker and a thinker; we have now to make him loving and tender-hearted, to perfect reason through feeling. (1993, p. 175)

Rousseau believes that Émile in puberty has to focus on the moral, emotional and aesthetic aspects of education in order to complete his education. The importance given to aesthetics is another meeting point with media literacy education. Martens observes that:

[...] historically, media literacy education has often been a synonym for learning to appreciate the aesthetic qualities of mass media, especially the cinematic arts. (2010, p. 8)

Rousseau's aims for cultivating Émile's aesthetic taste are very much in line with one of the goals of media education: he (similarly to media educators) intends to cultivate Émile's reliance on his own inner resources and prepare him for selfsufficiency (Jimack, 1993, p. xxxi).

The purpose of this first part of the article was to see how Rousseau's treatise can be used for understanding and advocating for the educational aims of media literacy. I argued that Rousseau's Émile is as timely as ever. As a backbone of modern education it can be successfully used in situating media literacy in a broader theoretical context. The following section focuses on John Stuart Mill's concept of utility in analyzing the importance of this specific subject in educational settings.

\section{A SATISFIED FOOL OR A MEDIA LITERATE SOCRATES?}

Kellner and Share argue that critical media literacy cannot be separated from radical democracy since this type of education develops skills for enhancing democratic skills and civic participation:

It takes a comprehensive approach that would teach critical skills and how to use media as instruments of social communication and change. The technologies of communication are becoming 
more and more accessible to young people and ordinary citizens, and can be used to promote education, democratic self- expression, and social progress. (Kellner \& Share, 2005, p. 373)

But why should one want that? Is it not enough to have a decent job that pays well? Why should one bother about things such as democracy, change or self-expression? Bentham (2009) would argue that for a well-paying and good job there is no need for media literacy education. It makes no sense in Bentham's utilitarian terms to receive an education that makes one more dissatisfied with the current state of democracy or with the media landscape.

In addition, there is a growing pressure from the market and some politicians to formulate the role of education in terms of employment. Unfortunately, more and more universities are also relying on this discourse when advertising their degrees. However, another famous utilitarian argues otherwise. Mill believes that:

It is better to be a human being dissatisfied than a pig satisfied; better to be Socrates dissatisfied than a fool satisfied. (1993, p. 10)

Mill's thoughts from "Utilitarianism" and "On Liberty" can be used to argue for a media literacy education that equips children and young people with the capacity of not digesting, but critically viewing media, among other advantages.

It is important to note though that, in contrast with Rousseau, Mill has no extended work on formal education. Yet Ryan (2011) observes that in fact, education is omnipresent in Mill's work, and that Mill made a differentiation between a "narrow" and a "wider" meaning of education. The "narrow" education was the formal one, while the "wider" embraced:

[...] all the influences that make us who and what we are. (Ryan, 2011, p. 653)

In Mill's writing whatever has an effect on our emotional, intellectual development can be considered educational in this broad sense (Ryan, 2011). It is not an easy task to categorize media literacy with these two concepts ("narrow" vs. "wide"). On the one hand, when formalized in school settings, media education would fit into the "narrow" group, but on the other, media are omnipresent in our society and have an effect on our development, thus it would also fit into the broader category. Either way this is another argument in favor of analyzing media literacy education in Millian terms.

Iona and James Tarrant (2004) argue against the usual characterization of Mill's utilitarianism as a hierarchy of "pleasures". The authors believe that Mill's utilitarianism can be better understood as a hierarchy of preferences because the former emphasizes the dependence of utility on the individual (Tarrant \& Tarrant, 2004, p. 109). The authors quote Mill in support of their interpretation:

[...] human beings have faculties more elevated than the animal appetites, and when once made conscious of them, do not regard anything as happiness which does not include their gratification. (Mill, 1993, p. 8) 
Mill goes even further by saying that:

[...] if the fool, or the pig, are of a different opinion, it is because they only know their side of the question. (Mill, 1993, p. 10)

This quote prompts the scholars to highlight that Mill has a very special understanding of utility, which "relies on the idea of a hierarchy of preferences, an individual whose faculties are 'more elevated' has better preferences" (Tarrant \& Tarrant, 2004, p. 110)

In this sense, Mill tells us that the individual after this development would consider him/herselferself to be better off:

[...] no intelligent being would consent to be a fool, no instructed person an ignoramus ... even though they should be persuaded that the fool is better satisfied with their lot than they are with theirs. (Mill, 1993, p. 9)

This framework is important in understanding the role of media literacy education in our everyday life. Within utilitarianism it is better to be a critical media literate person than one who is ignorant, even though this critical existence does not bring satisfaction. Media literacy education challenges accepted values and beliefs, and it does not offer contentment. And yet, if we use Mill's utility concept, we can argue that the person who becomes media literate will prefer her posteducation way of life. This person will prefer to understand how media conglomerates work, why Disney princesses look the way they do, and why certain media outlets present news using specific frames. This person will prefer to being critical to being a fool resting in blissful ignorance.

Iona and James Tarrant (2004, p. 113) argue that an education whose primary goal is "serving the daily uses of life" might not increase utility in this broad sense. What they are referring to is that education should be much more than satisfying market needs. In this sense media literacy offers a type of knowledge that goes well beyond economic interests. Media literacy education aims to empower citizens in understanding the societies in which they are living in, but it also aims to strengthen their participation in the democratic dialogue. In Mill's terms media literacy will educate individuals in order to transform their preferences to better ones. According to Mill's understanding of utility, it would serve countries to educate people to the level of Socrates. Media literacy education could be one step towards that level.

\section{CONCLUSIONS}

The aim of this article was to position media literacy in the broader theoretical context of Rousseau's notion of education and Mill's utilitarianism. As highlighted in the beginning of the paper, media literacy is a new scientific field, and it still has 
to struggle for recognition and a place in the formal or informal curricula of educational systems. I analyzed the aims of media literacy through the theoretical frameworks developed by Rousseau and Mill in order to see how this new field can be connected to modern social thought.

For a better understanding of the educational aims of media literacy I used Rousseau's Émile. I drew parallels between the goals of media literacy education (e.g. the development of critical thinking or the importance of media production) and Rousseau's advice on modern education. Rousseau's texts proved to be a good source for situating media literacy not only in a broader theoretical, but also in a pedagogical context.

For proving the overall role of media education in serving society at large, I used Mill's concept of utility. By understanding Mill's utilitarianism as a hierarchy of preferences, I argued that media literacy serves its purpose because it helps societies in educating people to reach Socrates's level of knowledge. I also highlighted that in Mill's terms it is better to be a media literate person than one who is ignorant, even though this critical thinking will not mean satisfaction.

In conclusion, media literacy scholars can rely on the work of both Rousseau and Mill in strengthening the position of this new field of study. Moreover, this new theoretical context can offer further arguments for experts in advocating for the introduction and strengthening of media literacy education worldwide.

\section{REFERENCES}

A Nemzeti Alaptanterv kiadásáról, bevezetéséről és alkalmazásáról [On the introduction, publication and application of the National Core Curriculum]. (2012). Retrieved July 12, 2015 from http:// ofi.hu/sites/default/files/attachments/mk_nat_20121.pdf.

Bentham, J. (2009). An Introduction to the Principles of Morals and Legislation. Mineola: Dover Publications Inc.

Cappello, G., Felini, D., Hobbs, R. (2011). Reflections on global developments in media literacy education: Bridging theory and practice. Journal of Media Literacy Education, 3 (2). Retrieved July 15, 2015 from http://digitalcommons.uri.edu/jmle/vol3/iss2/1.

Core Principles of Media Literacy Education in the United States. Retrieved May 2, 2015 from http:// namle.net/publications/core-principles.

Cranston, M. (1991). The Noble Savage: Jean-Jacques Rousseau 1754-1762. Chicago: The University of Chicago Press.

European Commission. (2015). Media literacy. Retrieved May 13, 2015 from http://ec.europa.eu/ culture/policy/audiovisual-policies/literacy_en.htm.

Fishekeller, J. (ed.). (2011). International Perspectives on Youth Media: Cultures of Production and Education. New York: Peter Lang.

Gerbner, G. (1963). Smaller than life: Teachers and schools in the mass media. Phi Delta Kappan, 44, pp. 202-205. Retrieved June 12, 2015 from http://www.asc.upenn.edu/gerbner/ archive. aspx?sectionID $=39$ \&packageID $=12$.

Hobbs, R. (1996). Teaching media literacy. In: Dennis, E., Pease, E. (eds). Children and the Media. New Brunswick: Transaction Press.

Jimack, P.D. (1993). Introduction to Rousseau, J.J., Émile. London: Everyman, pp. i-xxxv. 
Kellner, D., Share, J. (2005). Toward critical media literacy: Core concepts, debates, organizations, and policy. Discourse: Studies in the Cultural Politics of Education, 26 (3), pp. 369-386.

Kellner, D., Share, J. (2007). Critical media literacy, democracy, and the reconstruction of education. In: Macedo, D., Steinberg, S.R. (eds.). Media Literacy: A Reader. Peter Lang: New York. Retrieved June 5, 2015 from http://sudikoff.gseis.ucla.edu/archive/pdfs/philosophy/Summary_Kellner_ CritLitDemocracy.pdf.

Martens, H. (2010). Evaluating media literacy education: Concepts, theories and future directions. Journal of Media Literacy Education, 2 (1). Retrieved May 15, 2015 from http://digitalcommons. uri.edu/jmle/vol2/iss1/1.

Mill, J.S. (1993). Utilitarianism. London: Everyman.

National Association of Media Literacy Education (NAMLE). (n.d.). Media Literacy Defined. Retrieved July 19, 2015 from http://namle.net/publications/media-literacy-definitions/.

Parry, G. (2001). Émile: Learning to be men, women, and citizens. In: Riley, P. (ed.). The Cambridge Companion to Rousseau. Cambridge: Cambridge University Press, pp. 247-272.

RobbGrieco, M. (2014). Why history matters for media literacy education. Journal of Media Literacy Education, 6 (2), pp. 3-22. Retrieved August 2, 2015 from http://digitalcommons.uri.edu/jmle/ vol6/iss $2 / 2$.

Rousseau, J.-J. (1993). Émile. London: Everyman.

Ryan, A. (2011). J.S. Mill on education. Oxford Review of Education, 37 (5), pp. 653-667.

Rushkoff, D. (1996). Playing the Future: How Kids Culture Can Teach Us to Thrive in an Age of Chaos. New York: Harper Collins.

Scheibe, C., Rogow, F. (2008). 12 Basic Ways to Integrate Media Literacy and Critical Thinking into Any Curriculum. Ithaca: Ithaca College.

Tarrant, I., Tarrant, J. (2004). Satisfied fools: Using J.S. Mill's notion of utility to analyse the impact of vocationalism in education within a democratic society. Journal of Philosophy of Education, 38 (1), pp. 107-120.

Thevenin, B., Mihailidis, P. (2012). The re-politicization of media literacy education. Journal of Media Literacy Education, 4 (1). Retrieved November 11, 2015 from http://digitalcommons.uri.edu/ jmle/vol4/iss1/6. 